\title{
HG-ICP-OES Technique, a Useful Tool for Arsenic Determination in Soft Water
}

\author{
ECATERINA ANCA SERBAN ${ }^{1}$, GABRIELA GEANINA VASILE ${ }^{1 *}$, TOMA GALAON ${ }^{1}$, \\ CORINA ENE ${ }^{2}$, LUOANA FLORENTINA PASCU ${ }^{1}$ \\ ${ }^{1}$ National Research and Development Institute for Industrial Ecology - ECOIND, 71-73 Drumul Podul Dambovitei Str., \\ 060652, Bucharest, Romania \\ ${ }^{2}$ Petroleum-Gas University of Ploiesti, Faculty of Economic Sciences, 39 Bucharest Blvd., 100680, Ploiesti, Romania
}

\begin{abstract}
This paper presents a fast, sensitive, linear and precise method for the determination of arsenic (As) at trace levels, from different types of water (drinking, mineral, surface water and groundwater) using hydride generation and optical emission spectrometry with inductively coupled plasma (HG-ICP-OES). In order to generate the hydride, the initial pretreatment of the samples with a mixture of potassium iodide and ascorbic acid is necessary, in hydrochloric acid medium for reducing the $\mathrm{As}^{5+}$ to $\mathrm{As}^{3+}$ ions and for the subsequent formation of the hydride from $\mathrm{As}^{3+}$ ions and sodium borohydride, in a continuous-flow cell. The quantification limit of the method ( $L O Q=0.43 \mu \mathrm{g} / L)$, the precision (3.41\%), the recovery yield (95\%) and the measurement uncertainty of $24 \%$ frame the method within the limits imposed by the acceptance criteria of an analytical method for arsenic determination. The proposed method was tested on several types of water, the obtained results being compared to those obtained by applying two sensitive and selective alternative methods using ICP-MS, respectively ultrasonic nebulizer and ICP-OES.
\end{abstract}

Keywords: arsenic, hydride generation, ICP-OES, drinking water, groundwater, mineral water

\section{Introduction}

Heavy metals are naturally occurring in the environment and they are considered pollutants when the values of the concentrations required by the legislation are exceeded and cause a change in the balance of the environmental components [1]. In the environment, heavy metals come from different sources: industrial activities, transport, fossil fuels, agriculture, urbanization and other human activities [2]. Waters pollution with heavy metals occurs due to direct or indirect discharges to the environment of waste leachate, emissions of industrial and domestic waste water, as well as due to natural disasters. The most common sources of heavy metals which reach the aquatic systems are the discharges of untreated wastewater or poorly treated wastewater [1]. As heavy metals existing in the aquatic sector cannot be decomposed or destroyed, some of them end up being dissolved in water, another part being bioaccumulated by aquatic plants and organisms, some settling in the bottom sediments, but most being transported along the watercourse as suspensions $[1 ; 3]$.

European Directive on drinking water 98/83 / EC, transposed into Romanian Legislation in the form of Law No. 458/2002 updated by Law No. 311 of 2004, imposes a concentration limit for arsenic of $10 \mu \mathrm{g} / \mathrm{L}$ in water intended for human consumption [7]. For mineral water, Romanian legislation in force imposes a maximum permissible limit of $10 \mu \mathrm{g} / \mathrm{L}$ for arsenic [4-6].

In recent years, numerous studies have been conducted to determine the arsenic species (As) in drinking, mineral, surface water and groundwater, in products within the food chain, due to the wellknown toxic and carcinogenic effects of its chemical forms and oxidation states [8-10].

The arsenic in natural water is predominant in inorganic forms, these being the trivalent and pentavalent forms, arsenite $\left(\mathrm{As}^{3+}\right)$ and arsenate $\left(\mathrm{As}^{5+}\right)$ respectively. Organic forms of arsenic are monomethyl arsenic acid (MMAA) and dimethyl arsenic acid (DMAA) [11-13].

*email: gabriela.vasile@incdecoind.ro 
Generally, arsenite is found in anaerobic conditions in groundwater, while arsenate is found in aerobic conditions in surface waters. The valence and inorganic arsenic species depend on the redox conditions and the groundwater $p \mathrm{H}$. The $\mathrm{As}^{3+}$ and $\mathrm{As}^{5+}$ species can be found in the deep waters either as a mixture or individually according to the $\mathrm{pH}$ of the water [11-12]. The arsenate species, $\mathrm{As}^{5+}$, is the dominant form in oxidizing conditions, while in reducing conditions, such as in deep water, the $\mathrm{As}^{3+}$ species are dominant.

Inorganic forms are more toxic than organic ones, and $\mathrm{As}^{3+}$ species are more toxic than $\mathrm{As}^{5+}$, hence it is necessary to determine the species in order to determine the water toxicity $[11 ; 13]$.

Long-term exposure to arsenic by ingesting drinking water, mineral water or groundwater contaminated with arsenic causes various conditions, such as skin, lung, bladder and kidney cancer, etc. [14].

There are a wide variety of analytical techniques that can be used to determine arsenic in the environment, so we can list the following: atomic absorption spectrometry coupled with the hydride generator (HG-AAS); electrothermal atomic absorption spectrometry with graphite furnace (ETAAS); atomic fluorescence spectrometry (AFS); inductive coupled plasma optical emission spectrometry (ICP-OES); inductive coupled plasma mass spectrometry (ICP-MS); X-ray spectrometry; capillary electrophoresis; gas chromatography (GC); high performance liquid chromatography (HPLC); ion chromatography (IC), etc. [8; 15-25]. Some of the techniques mentioned above can be coupled with hydride generation (HG) to increase sensitivity and selectivity by removing interferences from the sample (HG-ETAAS; HG-AFS; HG-ICP-OES; HG-ICP-MS). In the presence of sodium borohydride, $\mathrm{As}^{3+}$ ions form volatile hydrides such as arsine, which are transported using an inert gas stream (argon) to the atomizer [21-24; 26-29]. Arsenic is then determined according to the type of detector in a different concentration range $(\mathrm{mg} / \mathrm{L}, \mu \mathrm{g} / \mathrm{L}, \mathrm{ng} / \mathrm{L})$ depending on the sensitivity of the detector.

The present study proposes a method for determining arsenic in low-contaminated waters (drinking water, mineral water, groundwater, surface water, spring water, raw water, non-carbonated water and carbonated water) using hydride generation and inductive coupled plasma optical emission spectrometry (HG-ICP-OES) with a state-of-the-art Perkin Elmer spectrometer (AVIO 500). The proposed method was verified by participating in international interlaboratory comparison schemes and by comparative studies on other analytical techniques: USN-ICP-OES technique (AVIO 500) and ICP-MS technique (7900 Agilent Technologies).

\section{Materials and methods}

\subsection{ICP-OES equipment and conditions}

For the experimental study, an inductively coupled plasma optical emission spectrometer ICP OES Avio 500 Perkin Elmer, with UV and VIS detectors, axial plasma view, was used.

$\mathrm{As}^{3+}$ determinations were performed using Perkin Elmer FIAS 400 equipment, an automatic flow injection system for hydride generation coupled to ICP-OES.

Comparative studies were performed with an Ultrasonic U6000AT + nebulizer, Teledyne, Cetac Technologies, coupled to ICP-OES and an inductively coupled plasma mass spectrometer ICP-MS model 7900 Agilent Technologies.

High quality water was obtained through an Ultrapure water system ELX Technology Inside MilliQ.

The operating conditions of the ICP-OES spectrometer and the hydride flow generation system are presented in Table 1.

Table 1. Operational parameters of HG-ICP-OES

\begin{tabular}{lccl}
\hline \multicolumn{5}{c}{ Spectrometer parameters } & Replicates & 3 \\
\hline As $\lambda: 188.979 \mathrm{~nm}, 197.197 \mathrm{~nm}$ & Transient Read Delay & $0.0 \mathrm{~s}$ \\
\hline Purge gas flow rate: & high & Transient Read Time & $15.0 \mathrm{~s}$ \\
\hline Integration time: & $0.05 \mathrm{~s}$ & & \\
\hline
\end{tabular}




\begin{tabular}{|c|c|c|c|c|c|}
\hline \multicolumn{6}{|c|}{ Plasma parameters } \\
\hline & Argon flow rate & $15 \mathrm{~L} / \mathrm{min}$ & & Power RF & $1350 \mathrm{~W}$ \\
\hline \multicolumn{4}{|c|}{ Agent auxiliary flow rate $0.2 \mathrm{~L} / \mathrm{min}$} & Plasma view & Axial \\
\hline \multicolumn{2}{|r|}{ Nebulizer flow rate } & $0.5 \mathrm{~L} / \mathrm{min}$ & & View distance & $15.0 \mathrm{~mm}$ \\
\hline \multicolumn{6}{|c|}{ Flow injection program } \\
\hline Step & Time (s) & $1(\mathrm{U} / \mathrm{min})$ & Pump 2 (U/min) & \multicolumn{2}{|r|}{ Valve } \\
\hline Prefil & 15 & 100 & 120 & \multicolumn{2}{|r|}{ Fill } \\
\hline 1 & 10 & 100 & 120 & \multicolumn{2}{|r|}{ Fill } \\
\hline 2 & 15 & 100 & 120 & \multicolumn{2}{|r|}{ Inject } \\
\hline \multicolumn{3}{|c|}{ Processing spectral peaks } & \multicolumn{3}{|c|}{ Processing time } \\
\hline \multicolumn{3}{|c|}{ Peak Algorithm: peak height } & \multicolumn{3}{|c|}{ Peak Algorithm: } \\
\hline \multicolumn{3}{|c|}{ Points per peak: } & \multicolumn{3}{|c|}{ Smoothing point: } \\
\hline
\end{tabular}

\subsection{Reagents}

For calibration, a Certified Reference Material (CRM) Arsenic standard for ICP, $1000 \mathrm{mg} / \mathrm{L}$ (Sigma-Aldrich) and a Reference Material (RM) Quality Control Standard 21, 100 mg/L (LGC) were used.

The comparative studies were performed with a $10 \mathrm{mg} / \mathrm{L}$ Multi-element Certified Reference Material (Agilent Technologies) and the analytical control was performed with a $100 \mathrm{mg} / \mathrm{L}$ Multielement Certified Reference Material (Merck).

For the determination of $\mathrm{As}^{3+}$, the following reagents and chemicals were used: sodium borohydride purum, $\geq 96 \%$; sodium hydroxide puriss $\geq 98 \%$, pellets; potassium iodide puriss 99 100.5\%; L-Ascorbic acid puriss 99.7-100.5\% (Sigma-Aldrich); hydrochloric acid 37\%; nitric acid ultrapure grade $69 \%$ (Merck);

Argon and Nitrogen purity type 5.0 (Linde-Gas) were used.

The quality control of the results was also achieved using a Certified Reference Material Matrix, water, code 5A, sample for hydride generation control of $\mathrm{As}^{3+}$, Aquacheck Scheme, LGC.

All calibration, hydride generation solutions and samples were prepared daily.

\subsection{Sample pretreatment} $H G-I C P-O E S$

The standard solutions for drawing the calibration curve and for the quality control of the results, respectively the water samples (drinking, mineral, surface water and groundwater) were pretreated in order to reduce the $\mathrm{As}^{5+}$ ions to $\mathrm{As}^{3+}$ ions. The reaction was carried out by adding $2 \mathrm{~mL}$ ultrapure $\mathrm{HCl}$ $37 \%(\mathrm{v} / \mathrm{v})$ and $10 \mathrm{~mL}$ of $5 \%$ potassium iodide solution (w/v) in 5\% (w/v) ascorbic acid solution added to an aliquot sample up to $35 \mathrm{~mL}$. Sample and standard solutions were brought to a volumetric flask of $50 \mathrm{~mL}$ with ultrapure water, the reduction reaction being carried out at room temperature for 45 minutes.

Hydride vapor generation was performed in a continuous-flow cell in FIAS 400 equipment using two types of solutions: a carrier solution of $10 \%(\mathrm{v} / \mathrm{v}) \mathrm{HCl}$, respectively, as reducing agent, $0.2 \%$ $\mathrm{NaBH}_{4}(\mathrm{w} / \mathrm{v})$ in $\mathrm{NaOH}$ solution (w/v) $0.05 \%$.

\section{$U S N-I C P-O E S, I C P-M S$}

The preparation of the water samples for these techniques was accomplished by filtering and acidifying them to a $p \mathrm{H}$ of less than 2 using ultrapure nitric acid.

The calibration curve for USN-ICP-OES was performed on the same concentration range as in HGICP-OES (4 - $20 \mu \mathrm{g} / \mathrm{L} \mathrm{As}$ ), while for ICP-MS a range of 2 - $10 \mu \mathrm{g} / \mathrm{L}$ As was used. 


\subsection{Method validation experimental tests}

The experimental studies performed for the in-house validation of the determination method of $\mathrm{As}^{3+}$ from water samples consisted in the determination of several performance parameters: limit of detection (LOD), limit of quantification (LOQ), linearity (calibration curve and homogeneity of dispersions test), accuracy (repeatability, intermediate precision), recovery test, selectivity (interference study), and uncertainty budget (Table 2). All precision and accuracy tests were performed at the same concentration of $10 \mu \mathrm{g} / \mathrm{L}$, which represents the maximum permissible limit for arsenic in drinking and mineral water according to the in-force legislation $[6,7]$.

The calibration curves were drawn using $1000 \mathrm{mg} / \mathrm{L}$ As CRM from Sigma Aldrich for ICP-OES (classic Meinhart nebulizer, respectively ultrasonic nebulizer), respectively $10 \mathrm{mg} / \mathrm{L}$ CRM from Agilent Technologies for ICP-MS.

The control of the results was performed using a RM type multi-element of $100 \mathrm{mg} / \mathrm{L}$ (LGC) for ICP-OES, respectively a CRM type multi-element of $100 \mathrm{mg} / \mathrm{L}$ (Merck) for ICP-MS.

The studies were conducted in two accredited laboratories that comply with the requirements of the SR EN ISO 17025: 2018 [30] reference regarding the control of the test results.

Table 2. Experimental tests for in-house validation studies of arsenic

\begin{tabular}{cc}
\hline LOD, LOQ & $1 \mu \mathrm{g} / \mathrm{L}, 5$ samples \\
\hline Linearity / Calibration curve & $4 \mu \mathrm{g} / \mathrm{L}, 8 \mu \mathrm{g} / \mathrm{L}, 12 \mu \mathrm{g} / \mathrm{L}, 16 \mu \mathrm{g} / \mathrm{L}, 20 \mu \mathrm{g} / \mathrm{L}$ \\
\hline Homogeneity of the dispersions test & $4 \mu \mathrm{g} / \mathrm{L}$ and $20 \mu \mathrm{g} / \mathrm{L}, 10$ determinations for each concentration \\
\hline Repeatability & $10 \mu \mathrm{g} / \mathrm{L}, 10$ determinations, one analyst, one day \\
\hline Intermediate precision & $10 \mu \mathrm{g} / \mathrm{L}, 4$ determinations, 3 days, 2 analysts \\
\hline Accuracy / recovery yield & drinking water enriched with $10 \mu \mathrm{g} / \mathrm{L}, 5$ determinations \\
\hline Equipment precision & $10 \mu \mathrm{g} / \mathrm{L}, 8$ repeated determinations from the same sample \\
\hline Selectivity - interference studies $(\mathrm{Fe}, \mathrm{Al})$ & $10 \mu \mathrm{g} / \mathrm{L}, 30 \mu \mathrm{g} / \mathrm{L}, 50 \mu \mathrm{g} / \mathrm{L}, 100 \mu \mathrm{g} / \mathrm{L}, 150 \mu \mathrm{g} / \mathrm{L}, 200 \mu \mathrm{g} / \mathrm{L}$ \\
& Each recovery test was performed 5 times
\end{tabular}

\section{Results and discussions}

\subsection{Linearity tests}

The linearity tests, consisting of the dispersions homogeneity test, the linearity test through the calibration curve for the determination of $\mathrm{As}^{3+}$ in drinking water, mineral water, surface water and groundwater were performed at three characteristic wavelengths for the arsenic, namely: $188.979 \mathrm{~nm}$, $193.693 \mathrm{~nm}$ and $197.197 \mathrm{~nm}$. The wavelength of $193.693 \mathrm{~nm}$ gave aberrant results for the arsenic concentration from real samples, the recovery yields being higher than $200 \%$, probably due to interference given by other metals (eg iron, aluminum). For these reasons, the results obtained at the performance parameters for this wavelength are not shown in this paper.

The calibration curve was performed on the concentration range of $4-20 \mu \mathrm{g} / \mathrm{L}$ from a $1000 \mathrm{mg} / \mathrm{L}$ MRC (Sigma-Aldrich). The results obtained in the linearity test and the curve parameters are presented in Table $3(\lambda=188.979 \mathrm{~nm})$, respectively Table $4(\lambda=197.197 \mathrm{~nm})$.

Table 3. Linearity results for As determination $(\lambda=188.979 \mathrm{~nm})$

\begin{tabular}{|c|c|c|c|c|c|c|}
\hline \multirow{5}{*}{$\begin{array}{l}\text { Calibration Curve } \\
\text { Parameters }\end{array}$} & $\mathrm{x}_{\mathrm{i}}(\mu \mathrm{g} / \mathrm{L})$ & 4 & 8 & 12 & 16 & 20 \\
\hline & $\mathrm{y}_{\mathrm{i}}\left(\mathrm{H}_{\text {peak }}\right)$ & 656 & 1342 & 1990 & 2694 & 3419 \\
\hline & \multicolumn{6}{|c|}{$y=-42.9+171.928 x$} \\
\hline & \multicolumn{2}{|c|}{$\mathrm{a}=-42.9$} & \multicolumn{2}{|c|}{$\mathrm{b}=171.928$} & & $\mathrm{R}=0.9998$ \\
\hline & \multicolumn{2}{|c|}{$S_{y}=15.2215$} & \multicolumn{3}{|c|}{$\mathrm{S}_{\mathrm{x} 0}=0.0885$} & $\mathrm{~V}_{\mathrm{x} 0}=0.74 \%$ \\
\hline \multicolumn{7}{|c|}{ Homogeneity of the dispersions test } \\
\hline$Y_{1 i}$ & $\mathrm{Y}_{10 \mathrm{i}}$ & & \multirow{7}{*}{\multicolumn{3}{|c|}{$\begin{array}{c}(\text { Variance } y 1)^{2}=466.2649 \\
(\text { Variance } y 10)^{2}=2197.198 \\
\text { PG } 10 / 1=4.712 \\
\text { PG } 1 / 10=0.212\end{array}$}} & \\
\hline 622.1 & 3050.8 & & & & & \\
\hline 622.6 & 3076.8 & & & & & \\
\hline 640.0 & 3110.3 & & & & & \\
\hline 643.1 & 3202.1 & & & & & \\
\hline 602.0 & 3087.9 & & & & & \\
\hline 594.7 & 2981.1 & & & & & \\
\hline
\end{tabular}




\begin{tabular}{llc}
\hline & & \\
\hline 566.9 & 3054.2 & $\mathrm{~F}(9,9,99 \%)=5.35$ \\
\hline 552.8 & 3132.1 & $\mathrm{PG}<\mathrm{F}(9,9,99 \%)$ \\
\hline 587.5 & 3064.5 & $4.712<5.35$ \\
\hline 579.7 & 3072.9 & \\
\hline
\end{tabular}

Table 4. Linearity results for As determination $(\lambda=197.197 \mathrm{~nm})$

\begin{tabular}{|c|c|c|c|c|c|c|}
\hline \multirow{5}{*}{$\begin{array}{l}\text { Calibration Curve } \\
\text { Parameters }\end{array}$} & $\mathrm{X}_{\mathrm{i}}(\mu \mathrm{g} / \mathrm{L})$ & 4 & 8 & 12 & 16 & 20 \\
\hline & $\mathrm{y}_{\mathrm{i}}\left(\mathrm{H}_{\text {peak }}\right)$ & 314 & 715 & 1044 & 1498 & 1919 \\
\hline & \multicolumn{6}{|c|}{$y=-99.5+99.785 x$} \\
\hline & \multicolumn{2}{|c|}{$a=-99.5$} & \multicolumn{2}{|c|}{$\mathrm{b}=99.785$} & \multicolumn{2}{|r|}{$\mathrm{R}=0.9968$} \\
\hline & \multicolumn{2}{|c|}{$S_{y}=22.1573$} & \multicolumn{2}{|c|}{$\mathrm{S}_{\mathrm{x} 0}=0.2220$} & \multicolumn{2}{|r|}{$\mathrm{V}_{\mathrm{x} 0}=1.85 \%$} \\
\hline \multicolumn{7}{|c|}{ Homogeneity of the dispersions test } \\
\hline $\mathrm{Y}_{1 \mathrm{i}}$ & $\mathrm{Y}_{10 \mathrm{i}}$ & & \multirow{11}{*}{\multicolumn{3}{|c|}{$\begin{array}{c}(\text { Variance } y 1)^{2}=1670.505 \\
(\text { Variance } y 10)^{2}=4508.676 \\
\text { PG } 10 / 1=2.699 \\
\text { PG } 1 / 10=0.371 \\
F(9,9,99 \%)=5.35 \\
\text { PG }<F(9,9,99 \%) \\
2.699<5.35\end{array}$}} & \\
\hline 273.1 & 1634.0 & & & & & \\
\hline 295.6 & 1654.2 & & & & & \\
\hline 297.8 & 1588.7 & & & & & \\
\hline 309.4 & 1744.3 & & & & & \\
\hline$\frac{307.4}{282.8}$ & 1694.9 & & & & & \\
\hline 263.1 & 1555.5 & & & & & \\
\hline$\frac{205.1}{269.5}$ & $\begin{array}{l}153 J . J \\
1596.4\end{array}$ & & & & & \\
\hline 336.0 & 1730.4 & & & & & \\
\hline 368.6 & 1671.6 & & & & & \\
\hline 378.5 & 1550.2 & & & & & \\
\hline
\end{tabular}

In order to verify the linearity, a linearity test was performed, in which the data were obtained from the calibration curve. The accepted linearity limits between which the linear calibration model can be applied with a known confidence level are $\pm 1 \%$ [15]. The linearity is calculated from the relation:

$$
\left(1-\mathrm{s}_{\mathrm{b}} / \mathrm{b}\right) \times 100
$$

where $\mathrm{s}_{\mathrm{b}}$ is the standard deviation of the slope, and $\mathrm{b}$ is the slope of the calibration curve.

The value $\mathrm{s}_{\mathrm{b}}$ is obtained from the formula:

$$
\mathrm{Sb}_{\mathrm{b}}=\sqrt{\frac{\boldsymbol{S}_{y 1}^{2}}{S_{x x}}}
$$

where: $S_{\mathrm{y} 1}$ is the residual standard deviation of the function, and $S_{\mathrm{xx}}$ is the sum of the squares of the differences between $\mathrm{x}_{\text {mean value }}$ and $\mathrm{x}_{\mathrm{i}}$.

The linearity value for the $\mathrm{As}^{3+}$ calibration curve within the $4-20 \mu \mathrm{g} / \mathrm{L}$ range at the wavelength of $188.979 \mathrm{~nm}$ is $99.3 \%$, while for the wavelength of $197.197 \mathrm{~nm}$ it is $99.86 \%$.

In the dispersions homogeneity test, the value $\mathrm{PG}=\mathrm{s}^{2}{ }_{10} / \mathrm{s}^{2}{ }_{1}\left(\mathrm{~s}^{2}{ }_{1}<\mathrm{s}^{2}{ }_{10}\right)$ was determined, obtaining $\mathrm{PG}=4.71$. Comparing the $\mathrm{PG}$ value with the table values of the $\mathrm{F}$ function (Fischer-Snedecor) for 9 degrees of freedom and $99 \%$ confidence interval, $\mathrm{F}_{9.9 ; 0.99}=5.35$, it can be observed that $\mathrm{PG}<\mathrm{F}_{9.9 ; 0.99}$. The deviations of the $s^{2}{ }_{1}$ and $s^{2}{ }_{10}$ dispersions are not significant, so there are no differences in the limits of the selected range.

The coefficient of variation of the method (relative standard deviation of the method) is $0.74 \%$. For concentrations higher than 1 ppm and lower than 10 ppm, CV (RSD) is between 7 and 11\% [15].

Comparative results at wavelengths of $188.979 \mathrm{~nm}$ versus $197.197 \mathrm{~nm}$ for As ${ }^{3+}$ indicated a better sensitivity (higher peak heights) at the wavelength of $188.979 \mathrm{~nm}$, as shown in Figure 1. Figure 2 shows the shape of $\mathrm{As}^{3+}$ peaks at the two wavelengths. 

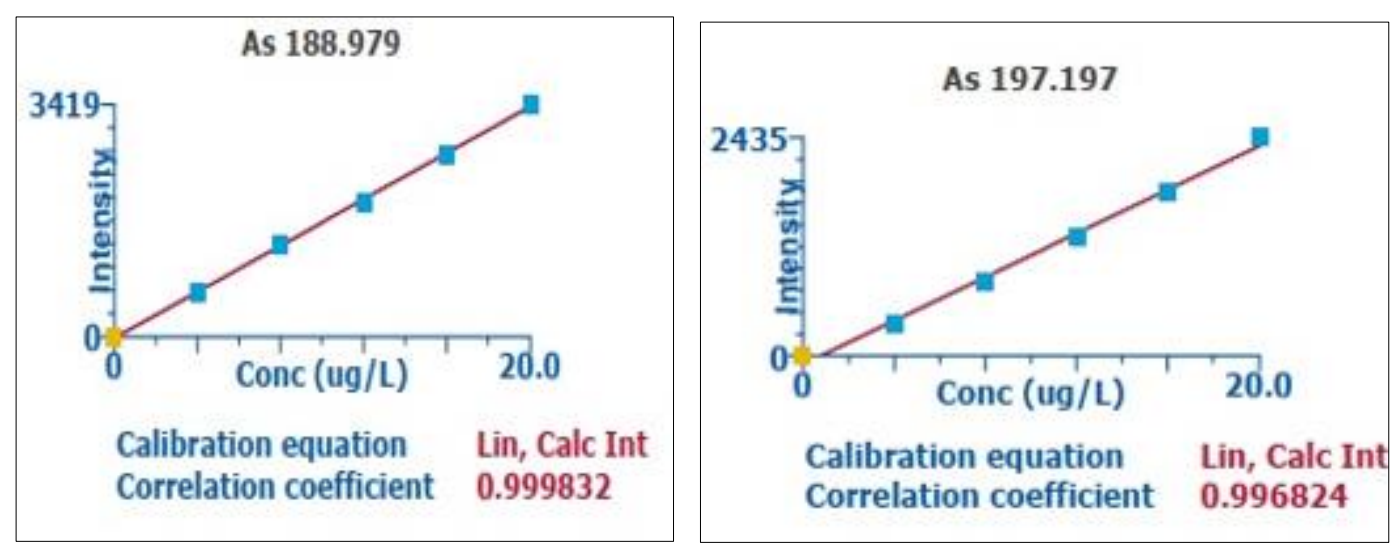

Figure 1. Calibration curve of $\mathrm{As}^{3+}(\lambda=188.979 \mathrm{~nm}, \lambda=197.197 \mathrm{~nm})$
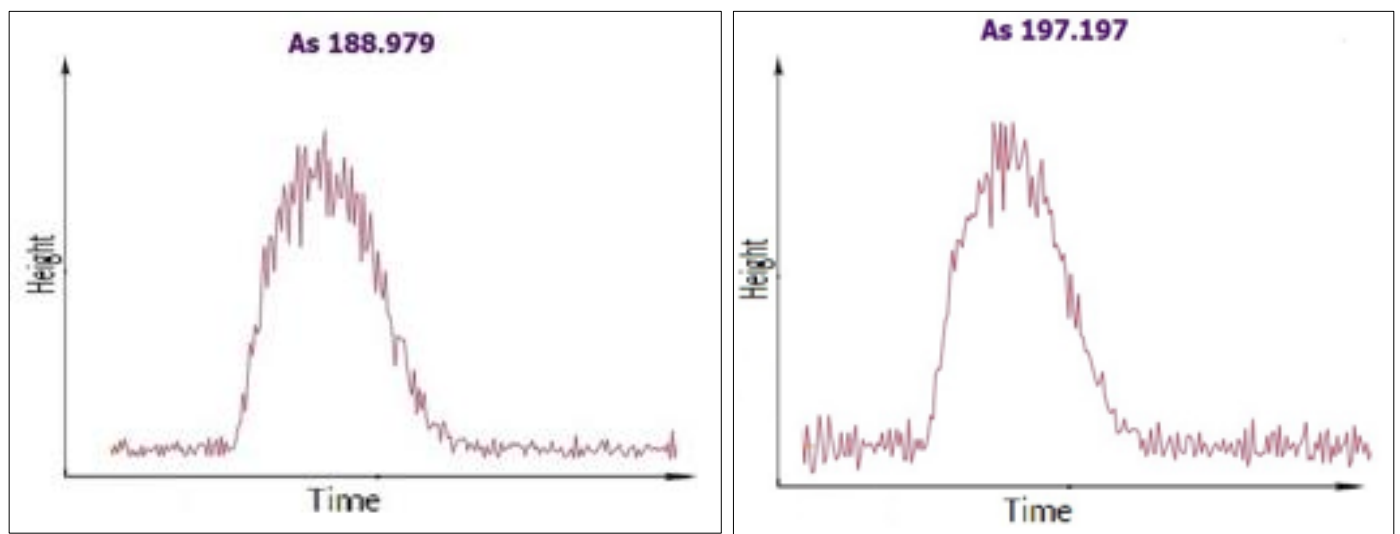

Figure 2. The height of the corresponding peaks for $\mathrm{As}^{3+}$ $(\lambda=188.979 \mathrm{~nm}, \lambda=197.197 \mathrm{~nm})$, at the concentration of $10 \mu \mathrm{g} / \mathrm{L}$

\subsection{Limit of detection, limit of quantification}

The values obtained when evaluating the parameters LOD and LOQ are presented in Table 5.

Table 5. In-house validation experiments - LOD, LOQ

\begin{tabular}{|c|c|c|c|c|c|}
\hline \multicolumn{6}{|c|}{$L O D, L O Q$ test $\lambda=188.979 \mathrm{~nm}$} \\
\hline$X_{\text {measured }}(\mu \mathrm{g} / \mathrm{L})$ & 1.358 & 1.392 & 1.359 & 1.462 & 1.415 \\
\hline $\mathbf{X}_{\text {mean valt }}$ & & 1.39 & \multicolumn{2}{|c|}{$\mathrm{s}(\mu \mathrm{g} / \mathrm{L})$} & 0.04 \\
\hline \multicolumn{2}{|c|}{$\mathrm{LOD}(\mu \mathrm{g} / \mathrm{L})$} & 0.13 & \multicolumn{2}{|c|}{$\mathrm{LOQ}(\mu \mathrm{g} / \mathrm{L})$} & 0.43 \\
\hline \multicolumn{6}{|c|}{$L O D, L O Q$ test $\lambda=197.197 \mathrm{~nm}$} \\
\hline $\mathrm{X}_{\text {measured }}(\mu \mathrm{g} / \mathrm{L})$ & 1.286 & 1.225 & 1.142 & 1.152 & 1.307 \\
\hline \multicolumn{2}{|c|}{$\mathrm{X}_{\text {mean value }}(\mu \mathrm{g} / \mathrm{L})$} & 1.22 & \multicolumn{2}{|c|}{$\mathrm{s}(\mu \mathrm{g} / \mathrm{L})$} & 0.08 \\
\hline \multicolumn{2}{|c|}{ LOD $(\mu \mathrm{g} / \mathrm{L})$} & $\mathbf{0 . 2 3}$ & \multicolumn{2}{|c|}{ LOQ $(\mu \mathrm{g} / \mathrm{L})$} & 0.75 \\
\hline
\end{tabular}

The limits of detection and quantification are below the maximum allowable values for drinking water quality [7], respectively of $1 \mu \mathrm{g} / \mathrm{L}$ for LOD and $3 \mu \mathrm{g} / \mathrm{L}$ for LOQ. It can be observed that at the wavelength of $188.979 \mathrm{~nm}$ these limits are about $57 \%$ smaller than at the wavelength of $197.197 \mathrm{~nm}$.

\subsection{Precision and recovery tests}

The results obtained in the precision tests (repeatability, intermediate precision) obtained at the maximum allowed concentration for As in drinking water $(10 \mu \mathrm{g} / \mathrm{L})$ are presented in Table 6 for both wavelengths. The repeatability and the intermediate precision expressed in the form of the relative standard deviation $\left(\mathrm{RSD}_{\mathrm{r}}, \mathrm{RSD}_{\mathrm{R}}\right)$ are well below the value indicated by the specialized literature for this concentration level, namely of maximum $21 \%$ [15], the registered values being of maximum $3.4 \%$. 
Table 6. Precision and recovery tests results in drinking water

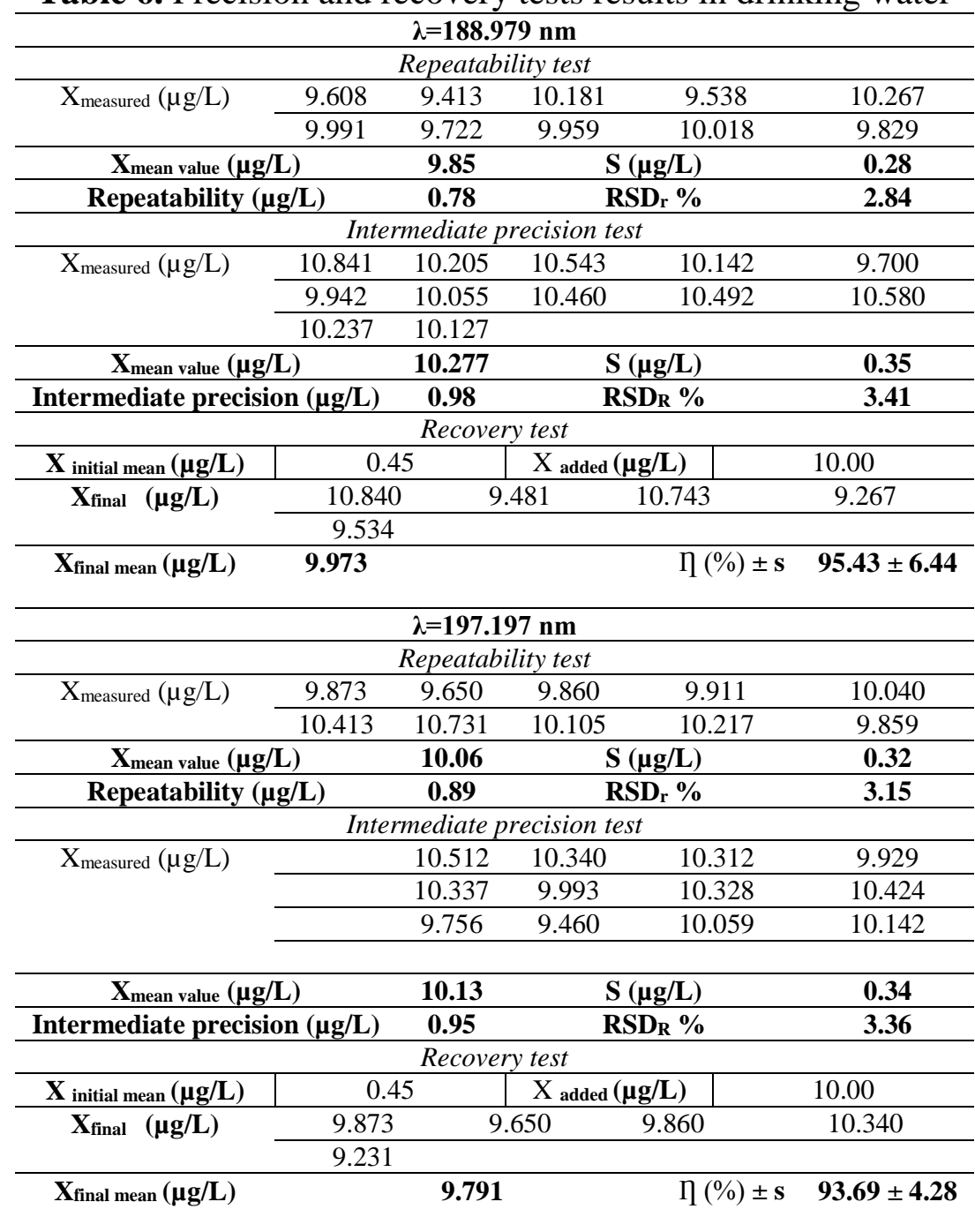

Also, the repeatability and the intermediate precision values expressed in $\mu \mathrm{g} / \mathrm{L}$ units are less than 1 $\mu \mathrm{g} / \mathrm{L}$, as required by the legislation in force for drinking water quality [7].

For concentrations of $10 \mu \mathrm{g} / \mathrm{L}$ the accuracy must be in the range $60-115 \%$ [15]. It can be observed that at both wavelengths the registered recoveries are over $93 \%$, at $188.979 \mathrm{~nm}$ the recovery is greater than at $197.197 \mathrm{~nm}$, the obtained value being $95.43 \%$ with a standard deviation of $6.44 \%$.

\subsection{Selectivity of the method, interference studies}

The selectivity tests for the As determination method using the HG-ICP-OES technique followed the studies of interference given by $\mathrm{Fe}$ and $\mathrm{Al}$ at $188.979 \mathrm{~nm}$ (Table 7) and $197.197 \mathrm{~nm}$ respectively (Table 8). For each recovery test, five separate samples were analyzed, the reported values being the mean values and the associated standard deviation.

Table 7. Recovery percentage for As in interference tests at $188.979 \mathrm{~nm}$

\begin{tabular}{cccc}
\hline $\begin{array}{c}\text { Iron concentration } \\
(\mu \mathrm{g} / \mathrm{L})\end{array}$ & \multicolumn{2}{c}{ Iron concentration $(\mu \mathrm{g} / \mathrm{L})$} & \multirow{2}{*}{$\begin{array}{c}\text { Recovery yield } \pm \text { standard } \\
\text { deviation }(\%)\end{array}$} \\
\cline { 2 - 3 } 0 & Added & Recovered mean & $100.1 \pm 0.26$ \\
\hline 10 & 10.000 & 10.01 & $103.3 \pm 0.26$ \\
\hline 30 & 10.000 & 10.34 & $104.8 \pm 0.37$ \\
\hline 50 & 10.000 & 10.49 & $92.7 \pm 1.29$ \\
\hline 100 & 10.000 & 9.28 & $88.3 \pm 1.76$ \\
\hline 150 & 10.000 & 8.83 & $87.4 \pm 1.87$ \\
\hline
\end{tabular}




\begin{tabular}{cccc}
\hline 200 & 10.000 & 8.10 & $80.9 \pm 2.60$ \\
\cline { 1 - 3 } $\begin{array}{c}\text { Aluminum concentration } \\
(\mu \mathrm{g} / \mathrm{L})\end{array}$ & \begin{tabular}{c} 
Aluminum concentration $(\mu \mathrm{g} / \mathrm{L})$ \\
\cline { 2 - 3 }
\end{tabular} & $\begin{array}{c}\text { Recovery yield } \pm \text { standard } \\
\text { deviation }(\%)\end{array}$ \\
\hline 0 & 10.000 & 9.97 & $99.74 \pm 0.25$ \\
\hline 10 & 10.000 & 9.99 & $100.2 \pm 0.76$ \\
\hline 30 & 10.000 & 9.78 & $98.0 \pm 1.02$ \\
\hline 50 & 10.000 & 9.27 & $93.0 \pm 1.71$ \\
\hline 100 & 10.000 & 9.18 & $92.1 \pm 2.66$ \\
\hline 150 & 10.000 & 9.24 & $94.7 \pm 3.00$ \\
\hline 200 & 10.000 & 9.29 & $93.1 \pm 0.51$ \\
\hline
\end{tabular}

Table 8. Recovery percentage for As in interference tests at $197.197 \mathrm{~nm}$

\begin{tabular}{cccc}
\hline $\begin{array}{c}\text { Iron concentration } \\
(\mu \mathrm{g} / \mathrm{L})\end{array}$ & \multicolumn{2}{c}{ Iron concentration $(\mu \mathrm{g} / \mathrm{L})$} & $\begin{array}{c}\text { Recovery yield } \pm \text { standard } \\
\text { deviation }(\%)\end{array}$ \\
\cline { 2 - 3 } 0 & Added & Recovered mean & $98.98 \pm 0.24$ \\
\hline 10 & 10.000 & 9.90 & $102.3 \pm 0.09$ \\
\hline 30 & 10.000 & 10.12 & $105.4 \pm 0.57$ \\
\hline 50 & 10.000 & 10.43 & $101.2 \pm 0.15$ \\
\hline 100 & 10.000 & 10.02 & $97.3 \pm 0.60$ \\
\hline 150 & 10.000 & 9.63 & $96.1 \pm 0.78$ \\
\hline 200 & 10.000 & 9.52 & $90.1 \pm 1.40$ \\
\hline Aluminum concentration & 10.000 & 8.99 & Recovery yield \pm standard \\
$(\mu \mathrm{g} / \mathrm{L})$ & Aluminum concentration $(\mu \mathrm{g} / \mathrm{L})$ & $100.3 \pm 0.47$ \\
\cline { 2 - 3 } 0 & Added & Recovered mean & $98.8 \pm 0.58$ \\
\hline 10 & 10.000 & 10.03 & $103.8 \pm 0.84$ \\
\hline 30 & 10.000 & 9.91 & $99.4 \pm 1.69$ \\
\hline 50 & 10.000 & 10.41 & $99.2 \pm 2.87$ \\
\hline 100 & 10.000 & 9.97 & $105.2 \pm 3.37$ \\
\hline 150 & 10.000 & 9.95 & $101.3 \pm 0.75$ \\
\hline 200 & 10.000 & 10.60 &
\end{tabular}

The conclusions of the interference tests indicate that in the case of $\mathrm{Fe}$, at both wavelengths analyzed, the recovery yield decreases as the concentration of $\mathrm{Fe}$ in the analyzed sample increases. The selected Fe values for the study ranged from $10 \mu \mathrm{g} / \mathrm{L}$ to $200 \mu \mathrm{g} / \mathrm{L}$, which represents the maximum concentration allowed in drinking water. For the wavelength of $188.979 \mathrm{~nm}$ it is observed that the reduction of the recovery yield is made even by $20 \%$ to the value of $200 \mu \mathrm{g} / \mathrm{L} \mathrm{Fe}$, while for 197.197 $\mathrm{nm}$ the recovery yield is reduced by $10 \%$. However, the obtained values fall within the recommended range for this concentration level, namely 60 - 115\% [15].

Regarding the possible interference given by $\mathrm{Al}$ it is observed that at $188.979 \mathrm{~nm}$ a maximum decrease of about $8 \%$ can be noted, while at $197.197 \mathrm{~nm}$ no significant variations of the recovery yield can be noted.

The uncertainty of the extended measurement was evaluated taking into account the data obtained in the linearity, intermediate precision and recovery tests [15;31-32], the calculated values being then compared with the maximum value allowed $3 \mu \mathrm{g} / \mathrm{L} \mathrm{[7]} \mathrm{according} \mathrm{to} \mathrm{the} \mathrm{in-force} \mathrm{legislation} \mathrm{(Table} \mathrm{9).}$

\subsection{Summary of the in-house validation}

The results obtained during the in-house validation tests for As from drinking water are summarized in Table 9 .

Table 9. Synthetic results obtained in the in-house validation process compared to the norms imposed for the quality control of drinking water

\begin{tabular}{ccc}
\hline Parameter & $\begin{array}{c}\text { Acceptance criteria according to drinking water } \\
\text { legislation }(\mu \mathrm{g} / \mathrm{L})\end{array}$ & Obtained values $(\mu \mathrm{g} / \mathrm{L})$ \\
\hline & As $(\boldsymbol{\lambda = 1 8 8 . 9 7 9} \mathbf{~ n m})$ & 0.49 \\
\hline Accuracy & $\leq 1$ & 0.78 \\
\hline Repeatability $(\mathrm{r})$ & $\leq 1$ & \\
\hline
\end{tabular}




\begin{tabular}{ccc}
\hline & & \\
\hline & $\leq 1$ & 0.98 \\
\hline Intermediate precision $\left(\mathrm{R}_{\mathrm{i}}\right)$ & $\leq 1$ & 0.13 \\
\hline Limit of detection $(\mathrm{LOD})$ & $\leq 3$ & 0.43 \\
\hline Limit of quantification $(\mathrm{LOQ})$ & $\leq 3 \mu \mathrm{g} / \mathrm{L}$ to $10 \mu \mathrm{g} / \mathrm{L}$ & $\mathrm{R}=0.9998$ \\
\hline Measurement uncertainty $\left(\mathrm{U}_{\mathrm{ex}}\right)$ & & 95.43 \\
\hline Linearity $(\mathrm{R})$ & $\mathbf{A s}(\mathbf{\lambda = 1 9 7 . 1 9 7} \mathbf{n m})$ & \\
\hline Recovery & $\leq 1$ & 0.24 \\
\hline & $\leq 1$ & 0.89 \\
\hline Accuracy & $\leq 1$ & 0.95 \\
\hline Repeatability $(\mathrm{r})$ & $\leq 1$ & 0.23 \\
\hline Intermediate precision $\left(\mathrm{R}_{\mathrm{i}}\right)$ & $\leq 3$ & 0.75 \\
\hline Limit of detection $(\mathrm{LOD})$ & $\leq 3 \mu \mathrm{g} / \mathrm{L}$ to $10 \mu \mathrm{g} / \mathrm{L}$ & \\
\hline Limit of quantification $(\mathrm{LOQ})$ & & $\mathrm{R}=0.9968$
\end{tabular}

The validation data indicated that the proposed method is suitable for the determination of As in drinking water at both wavelengths, specifying that in the case of high Fe concentrations $(\geq 200 \mu \mathrm{g} / \mathrm{L})$ it is indicated that As be quantified at a wavelength of $197.197 \mathrm{~nm}$.

\subsection{Real samples analyses}

Several types of water samples (drinking water, surface water, mineral water and groundwater) were analyzed both by the proposed method and by two other sensitive methods using ICP-MS, respectively USN-ICP-OES. The types of analyzed samples and the sampling locations are presented in Table 10.

Table 10. Description of the water samples collected

\begin{tabular}{|c|c|c|c|}
\hline $\begin{array}{l}\text { Sample } \\
\text { code }\end{array}$ & Description & $\begin{array}{l}\text { Sample } \\
\text { code }\end{array}$ & Description \\
\hline $\mathrm{DW}_{1}$ & Drinking water, Ilfov & $\mathrm{GW}_{2}$ & Groundwater, Galati \\
\hline $\mathrm{DW}_{2}$ & Drinking water, Ilfov & $\mathrm{GW}_{3}$ & Groundwater, Galati \\
\hline $\mathrm{DW}_{3}$ & Drinking water, Ploiesti & $\mathrm{GW}_{4}$ & Groundwater, Ploiesti \\
\hline $\mathrm{DW}_{4}$ & Drinking water, Ploiesti & $\mathrm{GW}_{5}$ & Groundwater, Tulcea \\
\hline $\mathrm{DW}_{5}$ & $\begin{array}{c}\text { Drinking water, Targoviste, } \\
\text { Dambovita }\end{array}$ & $\mathrm{GW}_{6}$ & Groundwater, Brazi, Prahova \\
\hline $\mathrm{DW}_{6}$ & Drinking water, Ploiesti & $\mathrm{GW}_{7}$ & Groundwater, Brazi, Prahova \\
\hline $\mathrm{DW}_{7}$ & Drinking water, Ilfov & $\mathrm{GW}_{8}$ & Groundwater, Ciofliceni, Ilfov \\
\hline $\mathrm{DW}_{8}$ & Drinking water, Bucharest & $\mathrm{GW}_{9}$ & Groundwater, Bucharest \\
\hline $\mathrm{DW}_{9}$ & Drinking water, Mioveni, Pitesti & $\mathrm{RW}_{1}$ & Raw water, Baia de Arama, Mehedinti \\
\hline $\mathrm{DW}_{10}$ & Drinking water, Bucharest & $\mathrm{RW}_{2}$ & Raw water, Mioveni, Pitesti \\
\hline $\mathrm{DW}_{11}$ & Drinking water, Bucharest & $\mathrm{RW}_{3}$ & Raw water, Dunare, zona Turnu Magurele \\
\hline $\mathrm{DW}_{12}$ & Drinking water, Craoiva, Dolj & $\mathrm{RW}_{4}$ & Raw water, Dunare, zona Turnu Magurele \\
\hline $\mathrm{DW}_{13}$ & Drinking water, Slatina, Olt & $\mathrm{RW}_{5}$ & Raw water, Dunare, zona Turnu Magurele \\
\hline $\mathrm{DW}_{14}$ & Drinking water, Slatina, Olt & $\mathrm{RW}_{6}$ & Raw water, Dunare, zona Turnu Magurele \\
\hline $\mathrm{DW}_{15}$ & Drinking water, Slobozia & $\mathrm{MW}_{1}$ & Mineral water, Timisoara \\
\hline $\mathrm{DW}_{16}$ & Drinking water, Slobozia & $\mathrm{MW}_{2}$ & Mineral water, Timisoara \\
\hline $\mathrm{DW}_{17}$ & Drinking water, Slobozia & $\mathrm{MW}_{3}$ & Mineral water, Timisoara \\
\hline $\mathrm{DW}_{18}$ & Drinking water, Slobozia & BW & Bottled water, Vidra, Ramnicu Valcea \\
\hline $\mathrm{DW}_{19}$ & Drinking water, Slobozia & SW & Sparkling water, Vidra, Ramnicu Valcea \\
\hline $\mathrm{DW}_{20}$ & Drinking water, Slobozia & $\mathrm{SuW}_{1}$ & Surface water, Ploiesti \\
\hline $\mathrm{DW}_{21}$ & Drinking water, Ploiesti & $\mathrm{SuW}_{2}$ & Surface water, Ploiesti \\
\hline $\mathrm{DW}_{22}$ & Drinking water, Ploiesti & $\mathrm{SpW}_{1}$ & Spring water, Valenii de Munte, Prahova \\
\hline $\mathrm{DW}_{23}$ & Drinking water, Ploiesti & $\mathrm{SpW}_{2}$ & Spring water, Valenii de Munte, Prahova \\
\hline $\mathrm{DW}_{24}$ & Drinking water, Mioveni, Pitesti & $\mathrm{SpW}_{3}$ & Spring water, Valenii de Munte, Prahova \\
\hline $\mathrm{GW}_{1}$ & Groundwater, Vanatori, Vrancea & OW & Osmosis water, Bucharest \\
\hline
\end{tabular}


Table 11. Arsenic concentration in different types of water and associated uncertainty value

\begin{tabular}{|c|c|c|c|c|c|c|c|c|c|}
\hline No. & $\begin{array}{l}\text { Sample } \\
\text { ID }\end{array}$ & Unit & $\begin{array}{c}\text { HG-ICP- } \\
\text { OES }\end{array}$ & USN-ICP-OES & No. & Sample ID & Unit & $\begin{array}{c}\text { HG-ICP- } \\
\text { OES }\end{array}$ & ICP-MS \\
\hline 1 & $\mathrm{DW}_{1}$ & $\mu \mathrm{g} / \mathrm{L}$ & $4.75 \pm 1.14$ & $4.56 \pm 0.91$ & 26 & $\mathrm{DW}_{15}$ & $\mu \mathrm{g} / \mathrm{L}$ & $1.97 \pm 0.47$ & $1.78 \pm 0.23$ \\
\hline 2 & $\mathrm{DW}_{2}$ & $\mu \mathrm{g} / \mathrm{L}$ & $4.60 \pm 1.10$ & $4.42 \pm 0.88$ & 27 & $\mathrm{DW}_{16}$ & $\mu \mathrm{g} / \mathrm{L}$ & $1.52 \pm 0.37$ & $1.41 \pm 0.18$ \\
\hline 3 & $\mathrm{DW}_{3}$ & $\mu \mathrm{g} / \mathrm{L}$ & $2.23 \pm 0.54$ & $2.11 \pm 0.42$ & 28 & $\mathrm{DW}_{17}$ & $\mu \mathrm{g} / \mathrm{L}$ & $1.52 \pm 0.37$ & $1.69 \pm 0.22$ \\
\hline 4 & $\mathrm{DW}_{4}$ & $\mu \mathrm{g} / \mathrm{L}$ & $<0.43$ & $<2.0$ & 29 & $\mathrm{DW}_{18}$ & $\mu \mathrm{g} / \mathrm{L}$ & $0.84 \pm 0.20$ & $0.87 \pm 0.11$ \\
\hline 5 & $\mathrm{DW}_{5}$ & $\mu \mathrm{g} / \mathrm{L}$ & $5.30 \pm 1.27$ & $5.15 \pm 1.03$ & 30 & $\mathrm{DW}_{19}$ & $\mu \mathrm{g} / \mathrm{L}$ & $1.13 \pm 0.27$ & $1.17 \pm 0.15$ \\
\hline 6 & $\mathrm{DW}_{6}$ & $\mu \mathrm{g} / \mathrm{L}$ & $2.04 \pm 0.49$ & $2.17 \pm 0.43$ & 31 & $\mathrm{DW}_{20}$ & $\mu \mathrm{g} / \mathrm{L}$ & $1.55 \pm 0.37$ & $1.40 \pm 0.18$ \\
\hline 7 & $\mathrm{DW}_{7}$ & $\mu \mathrm{g} / \mathrm{L}$ & $5.23 \pm 1.26$ & $5.39 \pm 1.08$ & 32 & $\mathrm{DW}_{21}$ & $\mu \mathrm{g} / \mathrm{L}$ & $0.89 \pm 0.21$ & $0.79 \pm 0.10$ \\
\hline 8 & $\mathrm{DW}_{8}$ & $\mu \mathrm{g} / \mathrm{L}$ & $3.36 \pm 0.81$ & $3.18 \pm 0.64$ & 33 & $\mathrm{DW}_{22}$ & $\mu \mathrm{g} / \mathrm{L}$ & $1.28 \pm 0.31$ & $1.10 \pm 0.14$ \\
\hline 9 & $\mathrm{DW}_{9}$ & $\mu \mathrm{g} / \mathrm{L}$ & $<0.43$ & $<2.0$ & 34 & $\mathrm{DW}_{23}$ & $\mu \mathrm{g} / \mathrm{L}$ & $2.08 \pm 0.50$ & $2.07 \pm 0.27$ \\
\hline 10 & $\mathrm{DW}_{10}$ & $\mu \mathrm{g} / \mathrm{L}$ & $<0.43$ & $<2.0$ & 35 & $\mathrm{RW}_{3}$ & $\mu \mathrm{g} / \mathrm{L}$ & $1.51 \pm 0.36$ & $1.59 \pm 0.21$ \\
\hline 11 & $\mathrm{DW}_{11}$ & $\mu \mathrm{g} / \mathrm{L}$ & $4.04 \pm 0.97$ & $4.23 \pm 0.85$ & 36 & $\mathrm{RW}_{4}$ & $\mu \mathrm{g} / \mathrm{L}$ & $1.64 \pm 0.39$ & $1.77 \pm 0.23$ \\
\hline 12 & $\mathrm{DW}_{12}$ & $\mu \mathrm{g} / \mathrm{L}$ & $<0.43$ & $<2.0$ & 37 & $\mathrm{RW}_{5}$ & $\mu \mathrm{g} / \mathrm{L}$ & $1.61 \pm 0.38$ & $1.54 \pm 0.20$ \\
\hline 13 & $\mathrm{DW}_{13}$ & $\mu \mathrm{g} / \mathrm{L}$ & $2.03 \pm 0.49$ & $<2.0$ & 38 & $\mathrm{RW}_{6}$ & $\mu \mathrm{g} / \mathrm{L}$ & $1.44 \pm 0.35$ & $1.31 \pm 0.17$ \\
\hline 14 & $\mathrm{DW}_{14}$ & $\mu \mathrm{g} / \mathrm{L}$ & $<0.43$ & $<2.0$ & 39 & $\mathrm{GW}_{4}$ & $\mu \mathrm{g} / \mathrm{L}$ & $0.82 \pm 0.20$ & $0.80 \pm 0.10$ \\
\hline 15 & $\mathrm{DW}_{24}$ & $\mu \mathrm{g} / \mathrm{L}$ & $<0.43$ & $<2.0$ & 40 & $\mathrm{GW}_{5}$ & $\mu \mathrm{g} / \mathrm{L}$ & $1.58 \pm 0.38$ & $1.66 \pm 0.22$ \\
\hline 16 & $\mathrm{RW}_{1}$ & $\mu \mathrm{g} / \mathrm{L}$ & $<0.43$ & $<2.0$ & 41 & $\mathrm{GW}_{6}$ & $\mu \mathrm{g} / \mathrm{L}$ & $0.93 \pm 0.22$ & $0.86 \pm 0.11$ \\
\hline 17 & $\mathrm{RW}_{2}$ & $\mu \mathrm{g} / \mathrm{L}$ & $<0.43$ & $<2.0$ & 42 & $\mathrm{GW}_{7}$ & $\mu \mathrm{g} / \mathrm{L}$ & $<0.43$ & $0.25 \pm 0.03$ \\
\hline 18 & $\mathrm{GW}_{1}$ & $\mu \mathrm{g} / \mathrm{L}$ & $2.57 \pm 0.62$ & $2.56 \pm 0.51$ & 43 & $\mathrm{SpW}_{1}$ & $\mu \mathrm{g} / \mathrm{L}$ & $14.33 \pm 3.44$ & $14.15 \pm 1.84$ \\
\hline 19 & $\mathrm{GW}_{2}$ & $\mu \mathrm{g} / \mathrm{L}$ & $2.09 \pm 0.50$ & $2.14 \pm 0.43$ & 44 & $\mathrm{SpW}_{2}$ & $\mu \mathrm{g} / \mathrm{L}$ & $16.41 \pm 3.94$ & $17.07 \pm 2.22$ \\
\hline 20 & $\mathrm{GW}_{3}$ & $\mu \mathrm{g} / \mathrm{L}$ & $2.11 \pm 0.51$ & $<2.0$ & 45 & $\mathrm{SpW}_{3}$ & $\mu \mathrm{g} / \mathrm{L}$ & $1.21 \pm 0.29$ & $1.18 \pm 0.15$ \\
\hline 21 & $\mathrm{GW}_{8}$ & $\mu \mathrm{g} / \mathrm{L}$ & $<0.43$ & $<2.0$ & 46 & $\mathrm{MW}_{1}$ & $\mu \mathrm{g} / \mathrm{L}$ & $1.16 \pm 0.28$ & $1.09 \pm 0.14$ \\
\hline 22 & $\mathrm{GW}_{9}$ & $\mu \mathrm{g} / \mathrm{L}$ & $3.92 \pm 0.94$ & $3.83 \pm 0.77$ & 47 & $\mathrm{MW}_{2}$ & $\mu \mathrm{g} / \mathrm{L}$ & $1.14 \pm 0.27$ & $1.15 \pm 0.15$ \\
\hline 23 & $\mathrm{BW}$ & $\mu \mathrm{g} / \mathrm{L}$ & $<0.43$ & $<2.0$ & 48 & $\mathrm{MW}_{3}$ & $\mu \mathrm{g} / \mathrm{L}$ & $1.07 \pm 0.25$ & $1.12 \pm 0.14$ \\
\hline 24 & SW & $\mu \mathrm{g} / \mathrm{L}$ & $<0.43$ & $<2.0$ & 49 & $\mathrm{SuW}_{1}$ & $\mu \mathrm{g} / \mathrm{L}$ & $0.78 \pm 0.18$ & $0.72 \pm 0.09$ \\
\hline 25 & OW & $\mu \mathrm{g} / \mathrm{L}$ & $<0.43$ & $<2.0$ & 50 & $\mathrm{SuW}_{2}$ & $\mu \mathrm{g} / \mathrm{L}$ & $0.81 \pm 0.19$ & $0.88 \pm 0.11$ \\
\hline
\end{tabular}

The results in Table 11 represent the mean of three determinations, each result being presented together with the associated measurement uncertainty.

As noted, the values recorded by the proposed method are comparable to those obtained by the ICP-MS method, which uses a standardized method [33]. All the analyzed water samples had the As concentration below the maximum value allowed by the legislation in force [6,7] except for two spring water samples which had higher values, obtained both by the HG-ICP-OES and also through ICP-MS technique.

\section{Conclusions}

This paper proposes a method for As determination from water samples using hydride generation and inductively coupled plasma optical emission spectrometry. Standardized methods for determining As at concentrations expressed in $\mu \mathrm{g} / \mathrm{L}$ units usually use ICP-MS, HG-AAS, or ET-AAS. The proposed method (HG-ICP-OES) was verified at two wavelengths $(188.979 \mathrm{~nm}$ and $197.197 \mathrm{~nm})$, and the results obtained at the tested parameters indicated that at $188.979 \mathrm{~nm}$ the method is more sensitive (lower LOD and LOQ), but selectivity is better at $197.197 \mathrm{~nm}$ (at Fe concentrations $\geq 200 \mu \mathrm{g} / \mathrm{L}$, higher recovery percentage than at $188.979 \mathrm{~nm}$ ). Thus, the proposed method is suitable for determining As at the concentrations required by the in-force laws for the control of both, drinking and mineral water. The method thus developed can be extended to other matrices such as aqueous extracts of plant organs.

Acknowledgments: The authors acknowledge the financial support offered by The National Research Program "Nucleu" through contract no 20N/2019, Project code PN 19040101.

\section{References}

1. FAIER CRIVINEANU, M., PERJU, D., DUMITREL, G.-A., SILAGHI PERJU, D., Mathematical models describing the emission and distribution of heavy metals in surface waters, Rev. Chim., 63(4), 2012, 435-439. 
2. JITAR (PLAVAN), O.A., Impact on the environment and bioaccumulation of heavy metals in aquatic organisms in the Romanian Black Sea sector, PhD thesis, Doctoral School of the Faculty of Chemical Engineering and Environmental Protection, Gheorghe Asachi Technical University of Iasi, 2012 [in Romanian]

3. ABDELDAYEM, R., A preliminary study of heavy metals pollution risk in water, Applied. Water Sci., 10(1), 2020, 1-4.

https://doi.org/10.1007/s13201-019-1058-x

4. CAPRA, L., MANOLACHE, M., ION, I., STOICA, R., ION, A.C., Validation and optimization of a method for Sb determination from bottled natural mineral waters by ICP-OES, Rev. Chim., 69(8), 2018, 2102-2106.

5. CAPRA, L., MANOLACHE, M., ION, I., ION, A.C., Validation of a method for determination of antimony in drinking water by ICP-OES, U.P.B. Sci. Bull., Series B, 78, Iss. 3, 2016, 103-112.

6.***Government Decision No. 1020/2005 on the approval of technical norms of exploitation and commercialization of natural mineral waters, as amended by Government Decision No. 532/2010, Romanian Official Monitor, Part I, No. 400 from $16^{\text {th }}$ of June 2010

7.***Law No. 458, 2002, on the quality drinking water modified and completed by Law No. 311/2004, Romanian Official Monitor, Part I, No. 582 from $30^{\text {th }}$ of June

8. ANAWARA, H.M., Arsenic speciation in environmental samples by hydride generation and electrothermal atomic absorption spectrometry - Review, Talanta, 88, 2012, 30-42.

9. DINU, C., UNGUREANU, E.M., VASILE, G.G., KIM, L., PASCU, L.F., SIMION, M., Evaluation of the bioavailability and pollution indexes of some toxic metals in polluted soils from an abandoned mining area, Rev. Chim., 69(11), 2018, 4141-4147.

10. DINU, C., UNGUREANU, E.M., VASILE, G.G., KIM, L., SIMION, M., IONESCU, I., ENE, C., Soil and vegetation pollution from an abandoned mining area situated in Hunedoara County, Romania, Rev. Chim., 69(1), 2018, 14-20.

11. CIFTCI, T.D., HENDEN, E., Arsenic speciation of waters from the Aegean Region, Turkey by hydride generation: atomic absorption spectrometry, Bull. Environ. Contam. Toxicol., 97, 2016, 272278.

12. NEGREA, A.G., New materials used to remove arsenic from water, Habilitation thesis, 2017 [in Romanian]

13. FIAMEGKOS, I., CORDEIRO, F., DEVESA, V., VÉLEZ, D., ROBOUCH, P., EMTEBORG, H., LEYS, H., CIZEK-STROH, A., DE LA CALLE, B., Determination of inorganic arsenic in food by flow injection hydride generation atomic absorption spectrometry (FI-HG-AAS), European Commission, 2015

14. VASILE G.G., DINU C., KIM L., TENEA A., SIMIO M., ENE C., SPINU C., UNGUREANU E.M., MANOLACHE D., Platinum group elements in road dust and vegetation from some European and national roads with intensive car traffic in Romania, Rev. Chim., 70(1), 2019, 286-292.

15. TANASE, GH., RADU, G.L., PANA, A., BULEANDRA, M., Validation of analytical methods. Theoretical principles and case studies, Editura Printech, 2007 [in Romanian]

16. STANCIU-BURILEANU, M.M., CONSTANTIN, L., LACATUSU, R., STROE, V.M., Determination of selenium content in soil and parent material by HG-AAS, Rev. Chim., 63(6), 2012, 553-556.

17. BOSE, U., RAHMAN, M., ALAMGIR, M., Arsenic toxicity and speciation analysis in groundwater samples: a review of some techniques, Int. J. Chem. Technol., 3(1), 2011, 14-25.

18. KOMOROWICZ, I., BARAŁKIEWICZ, D., Determination of total arsenic and arsenic species in drinking water, surface water, wastewater, and snow from Wielkopolska, Kujawy-Pomerania, and Lower Silesia provinces, Poland, Environ. Monit. Assess., 188( 9), 504, 2016, 1-22.

19. TYSON, J., The determination of arsenic compounds: a critical review, Hindawi Publishing Corporation, ISRN Anal. Chem., 2013, 1-24.

https://doi.org/10.1155/2013/835371 
20. GUERRA, M.B.B., CARAPELli, R., KELBER, M., ARAUJO NOGUEIRA, A.R., PEREIRAFILHO, E.R., Determination of $\mathrm{As}$ and $\mathrm{Sb}$ in mineral waters by fast sequential continuous flow hydride generation atomic absorption spectrometry, Anal. Methods, 3, 2011, 599-605.

21. HU, P., WANG, X., WANG, Z., DAI, R., DENG, W., YU, H., HUANG, K., Recent developments of hydride generation in non-atomic spectrometric methods, Trends Anal. Chem., 119, 2019, 1-9. https://doi.org/10.1016/j.trac.2019.07.028

22. MIKHEEV, I.V., KARPUKHINA, E.A., USOL'TSEVA, L.O., SAMARINA, T.O., VOLKOV, D.S., PROSKURNIN, M.A., Application of microwave plasma atomic emission spectrometry and hydride generation for determination of arsenic and selenium in mineral water, Inorg. Mater., 53(14), 2017, 1422-1426.

23. YOUSEFI, S.R., ZOLFONOUN, E., On-line determination of ultra-trace of antimony species via hydride generation technique using ultrasonic nebulization system coupled to ICP-OES, J. Iran. Chem. Soc., 16, 2019, 979-984.

24. MIREA, C.M., DIACONU, I., ŞERBAN, E.A., RUSE, E., Establishing performance parameters to determine manganese using UV-VIS molecular absorption spectrometry, U.P.B. Sci. Bull., Series B, 77, Iss. 3, 2015, 103-114.

25. MIREA, C.M., DIACONU, I., RUSE, E., ŞERBAN, E.A., CLEJ, D.D., POPA, G.A., POPA (ENACHE), D.F., NECHIFOR, GH., The removal of heavy metals using the bulk liquid membrane technique, Prog. Cryo. Isso. Sep., 19, Iss. 1, 2016, 45-54.

26. DINU, C., VASILE, G., CRUCERU, L., Advanced analytical methods for mercury determination in slightly contaminated water samples, J. Environ. Prot. Ecol., 14(4), 2013, 1515-1524.

27. VASILE, G., DINU, C., CRUCERU, L., PETRE, J., Distribution water materials and tap water quality, Environ. Eng. Manag. J., 9(11), 2010, 1465-1471.

28. NUGRAHA, W.C., ELISHIAN, C., KETRIN, R., Determination of total arsenic in fish by hydride-generation atomic absorption spectrometry: method validation, traceability and uncertainty evaluation, IOP Conf. Series: Earth Environ. Sci., 60, 2017, 1-11.

29. CHOOTO, P., MUAKTHONG, D., INNUPHAT, C., PUCHONG, W., Determination of inorganic arsenic species by hydride generation-inductively coupled plasma optical emission spectrometry, Science Asia, 42, 2016, 275-282.

30.***ISO 17025:2018 General requirements for the competence of testing and calibration laboratories.

31. POPESCU, I.L., ABOUL-ENEIN, H., TANASE, I.GH., GHICA, I., BALA, C., Validation of a quantitative method determination of estradiol in pharmaceutical products using UV-Vis molecular absorption spectrometry, Anal. Lett., 41(18), 2008, 3272-3296.

32. DIACONU, I., ABOUL-ENEIN, H.Y., BUNACIU, A., TĂNASE, I. G., Estimation of uncertainty for measuring codeine phosphate tablets formulation using UV-Vis spectrophotometry, Anal. Lett., 43(7-8), 2010, 1207-1216.

33.***ISO 17294-2:2016 Water quality - Application of inductively coupled plasma mass spectrometry (ICP-MS) - Part 2: Determination of selected elements including uranium isotopes.

Manuscript received: 15.04 .2020 